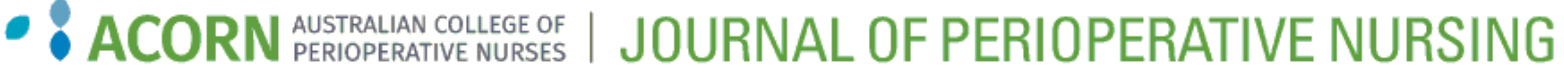

Volume 30 | Issue 4

Article 1

$12-1-2017$

\title{
A review of suspected intraoperative antiseptic burns: A quality improvement review
}

Follow this and additional works at: https://www.journal.acorn.org.au/jpn

Part of the Health Services Administration Commons, Health Services Research Commons, Perioperative, Operating Room and Surgical Nursing Commons, and the Surgery Commons

(c) (†)

This work is licensed under a Creative Commons Attribution 4.0 License.

\section{Recommended Citation}

Stankiewicz, Monica and Wyland, Michele (2017) "A review of suspected intraoperative antiseptic burns: A quality improvement review," Journal of Perioperative Nursing: Vol. 30 : Iss. 4 , Article 1.

Available at: https://doi.org/10.26550/2209-1092.1018

https://www.journal.acorn.org.au/jpn/vol30/iss4/1

This Article is brought to you for free and open access by Journal of Perioperative Nursing. It has been accepted for inclusion in Journal of Perioperative Nursing by an authorized editor of Journal of Perioperative Nursing. 


\section{Authors}

Monica Stankiewicz

MAppSci (Research), MNursSc(NP), GradDip WM, GradCert STN

Clinical Nurse Consultant, Wound Management and Stomal Therapy Department

Redcliffe Hospital

Redcliffe 4020

Michele Wyland

MHlthSciEd, BA, GradCert Mgt, RN Nurse Educator, Surgical Services

Redcliffe Hospital

Redcliffe 4020

\section{A review of suspected intra- operative antiseptic burns: A quality improvement review}

\section{Introduction}

The use of antiseptics in theatre is mainstay treatment in reducing cutaneous bioburden ${ }^{1}$ and, in turn, preventing surgical site infection and sepsis ${ }^{2,3}$. Typically, aqueous betadine and chlorhexidine in alcohol are preferred $^{3}$. Aqueous betadine is a broad-spectrum antiseptic with a quick kill rate but is deactivated by organic material on the patient's skin $^{3}$. More effective than aqueous betadine is chlorhexidine gluconate it is also a broad-spectrum antiseptic but is not deactivated by organic compounds on the patient's skin ${ }^{3}$.

The incidence of antiseptic chemical burns is a rare but recognised potential adverse intra-operative event ${ }^{4}$. Wall and colleagues ${ }^{5}$ highlighted that antiseptic burns are also termed 'irritant contact dermatitis'. Symptoms include pain at the area of direct contact ${ }^{5}$ and skin changes including changes from erythema and blistering to skin necrosis ${ }^{5}$. These changes are symptomatic of burns ranging in severity from superficial burns to deep dermal-subcutaneous (full thickness) burns ${ }^{6}$. Antiseptic burns require management via the burns protocol pathway and are reported to take several weeks to heal ${ }^{6}$.

There are several known factors which contribute to the development of antiseptic burns intra-operatively. These include $\mathrm{e}^{1,5,7}$ :

- concentration of the antiseptic

- absorption into the skin, patient factors allowing permeability or resistance to absorption

- exposure time

- occlusion

- humidity and moisture.
These factors are more likely to occur in combination in the operating theatre than in any other health environment. This is because antiseptics are at concentrations necessary to provide adequate asepsis and are applied to immobile, unconscious patients. Burns, in this brief, were reported in areas of occlusion such as between the patient and the operating table, and between the patient and a device (tourniquet).

Queensland Health's Work Unit Guidelines (WUG) ${ }^{8}$ in theatre highlight potential risks associated with antiseptics:

- 'Alcoholic preparations are a fire risk; therefore, it is vital to prevent pooling of solution, remove under pads that are soaked with skin preparation solutions prior to draping and allow time for skin preparations to dry prior to placement of drapes to prevent a build-up of vapour.' $8(p, 1)$

- 'Selection of antimicrobial agent is based on: patient sensitivity, the operative site, conditions of the patient's skin, surgeons' preference, patients preoperative shower and/or compound scrub; all should be of the same antimicrobial solution.' ${ }^{8(p, 1)}$

- '... the prevention of pooling of solutions underneath the patient and beneath the pneumatic tourniquet, to minimise the risks of chemical burns to the skin and or a source of ignition. All wet drapes/ under pads should be removed from the patient area after the skin prep is complete.' ${ }^{8(p, 1)}$ 


\section{Method}

This quality improvement activity required a review of all operating theatre incidents logged for 2015 through the hospital's incident database. A chart review was then conducted of all suspected intraoperative burns injuries. Seven charts were highlighted in the review. Results and outcomes were reported to management with strategies put in place to improve patient outcomes and minimise future risk.

\section{Analysis}

\section{Incident and chart reviews}

Table 1 summarises patient demographics, adverse events, antiseptic and occlusion time.

- This patient grouping did not recover in a single post-operative ward - both a specialised surgical ward and a maternity ward accepted these patients.

- There is no consistency - asepsis was provided by treating teams, surgeons and nursing staff who included a diversity of skill level, that is, junior and senior staff.

- There are no consistent comorbidities or surgical procedures among those harmed.

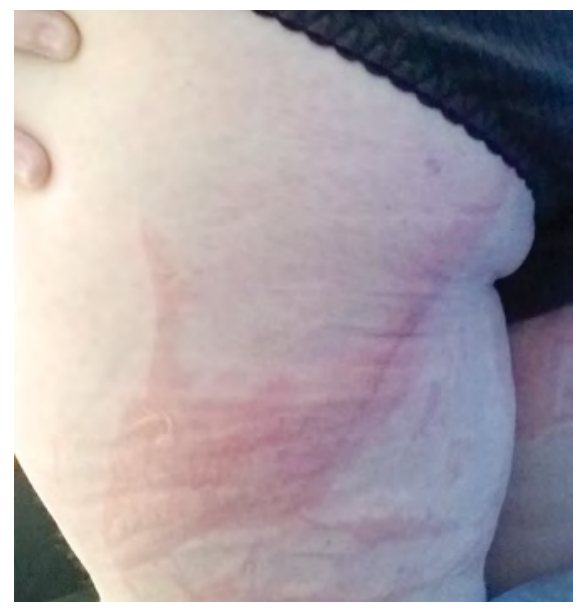

Figure 1: Erythema and blistering
- Only aqueous betadine or chlorhexidine in alcohol were used as antiseptics.

A total of seven patients were highlighted with suspected antiseptic burns. Three patients were confirmed to have developed the injury post-operatively. This assessment was completed by the hospital's specialised wound service.

Two of these patients are known to have antiseptic burns. They were both maternity patients who had caesarean sections. The burns took 48 hours to develop into blisters. Initial injury noted was 'erythema'. One of these patients was referred for a 'pressure injury'; upon review it was noted that the injury was not consistent with a pressure injury and that an antiseptic burn was the likely cause. The other patient had reported the injury upon discharge to the hospital's patient liaison officer. With the latter patient, it was known that her skin was compromised preoperatively as she had developed a rash, polymorphic eruption of pregnancy (PEP), which may have increased the permeability of the antiseptic through the damaged skin?. This patient consented for her injuries to be photographed (see figures 1 to 3 ). It should be noted that on day two postoperative, this patient reported developing

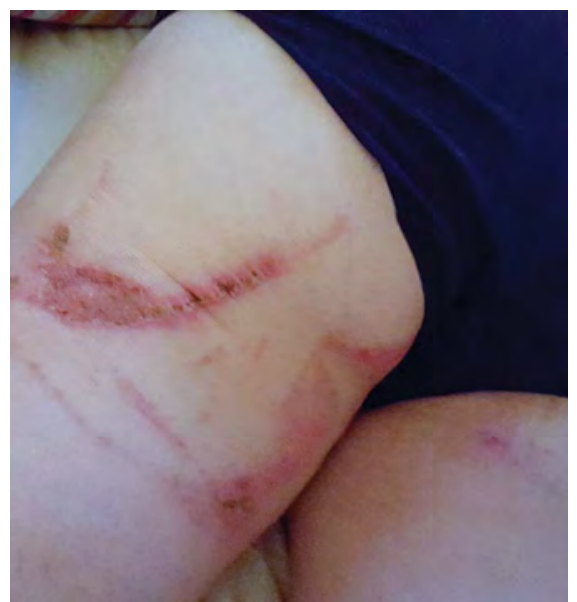

Figure 2: Wound with epidermal loss erythema, blistering and pain on her thighs (Figure 1). This progressed to a wound with epidermal loss into the dermis (Figure 2) and the wound healing with immature scar tissue present (Figure 3).

The third patient who was reviewed was asked to seek the opinion of a dermatologist. At the time of injury development and during subsequent reviews this patient reported a life-long skin sensitivity to tapes; therefore, despite the injuries occurring intra-operatively, a differential diagnosis of blistering disorder needs to be considered.

Two patients had tourniquet injuries. One young male sustained injury after 23 minutes and an elderly gentleman had an injury develop after 93 minutes of tourniquet application. The elderly patient had an internal review of the incident at the time and it was suspected that the injury may have been related to prolonged use of the tourniquet, although the duration was considered appropriate. In light of recent skin injuries, burn by antiseptic cannot be ruled out.

Another patient reported a groin burn post hysteroscopy dilation and curettage ( $D$ \& C ) for vaginal bleeding. The patient's notes highlighted that there was no cauterisation required.

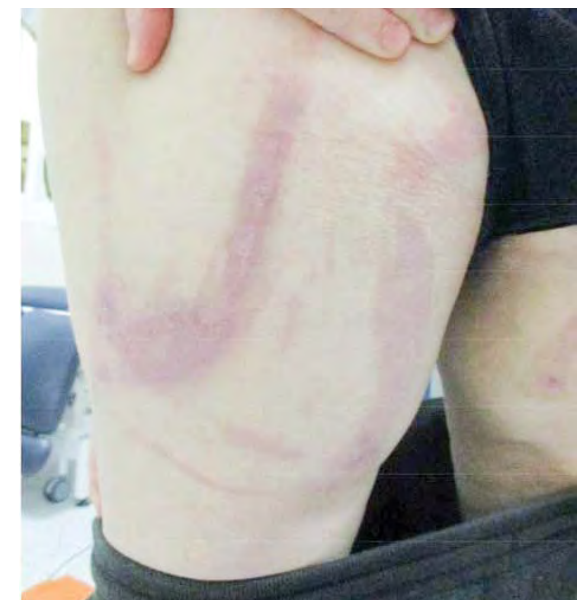

Figure 3: Wound healing 
Table 1: Chart review from injuries identified via incident reports

\begin{tabular}{|c|c|c|c|c|c|c|}
\hline Patient & $\begin{array}{l}\text { Location of } \\
\text { injury }\end{array}$ & $\begin{array}{l}\text { Type of } \\
\text { operation }\end{array}$ & $\begin{array}{l}\text { Patient } \\
\text { demographics }\end{array}$ & $\begin{array}{l}\text { Type of } \\
\text { antiseptic }\end{array}$ & Occlusion method & $\begin{array}{c}\text { Duration of } \\
\text { occlusion }\end{array}$ \\
\hline 1 & $\begin{array}{l}\text { tourniquet cuff } \\
\text { left upper arm }\end{array}$ & $\begin{array}{l}\text { wire removed } \\
\text { from elbow }\end{array}$ & 15-year-old male & $\begin{array}{l}\text { chlorhexidine } \\
0.5 \% \text { in alcohol } \\
\text { red }\end{array}$ & tourniquet $220 \mathrm{mmHg}$ & 23 minutes \\
\hline 2 & tourniquet burn & $\begin{array}{l}\text { left total } \\
\text { knee } \\
\text { replacement }\end{array}$ & $\begin{array}{l}\text { 84-year-old male } \\
\text { with asthma, } \\
\text { asbestos } \\
\text { polymyalgia } \\
\text { rheumatica }\end{array}$ & $\begin{array}{l}\text { chlorhexidine } \\
0.5 \% \text { in alcohol } \\
\text { red }\end{array}$ & $\begin{array}{l}\text { tourniquet } 350 \mathrm{mmHg} \\
\text { diathermy plate right } \\
\text { thigh }\end{array}$ & 97 minutes \\
\hline 3 & burn to groin & $\begin{array}{l}\text { hysteroscopy } \\
\text { D\&C for } \\
\text { vaginal } \\
\text { bleeding }\end{array}$ & $\begin{array}{l}\text { 45-year-old } \\
\text { female with } \\
\text { medical history of } \\
\text { premature ovarian } \\
\text { failure }\end{array}$ & $\begin{array}{l}\text { aqueous } \\
\text { betadine }\end{array}$ & $\begin{array}{l}\text { No curettage as } \\
\text { no bleeding. Does } \\
\text { not stipulate that } \\
\text { hyfrecation was } \\
\text { required. }\end{array}$ & 5 minutes \\
\hline 4 & sacral burn & $\begin{array}{l}\text { Caesarean } \\
\text { section }\end{array}$ & $\begin{array}{l}\text { 29-year-old } \\
\text { female with nil } \\
\text { comorbidities }\end{array}$ & $\begin{array}{l}\text { aqueous } \\
\text { betadine }\end{array}$ & $\begin{array}{l}\text { contact with theatre } \\
\text { table diathermy plate } \\
\text { right thigh }\end{array}$ & 110 minutes \\
\hline \multirow{2}{*}{5} & \multirow{2}{*}{$\begin{array}{l}\text { chemical burn } \\
\text { on back and } \\
\text { leg (possibly } \\
\text { reaction to tape) }\end{array}$} & \multirow{2}{*}{$\begin{array}{l}\text { right total } \\
\text { knee } \\
\text { replacement }\end{array}$} & \multirow{2}{*}{$\begin{array}{l}\text { 67-year-old } \\
\text { female with } \\
\text { medical history } \\
\text { of osteoarthritis } \\
\text { and known tape } \\
\text { sensitivities, } \\
\text { notably } \\
\text { Elastoplast TM }\end{array}$} & \multirow{2}{*}{$\begin{array}{l}\text { chlorhexidine } \\
0.5 \% \text { in alcohol } \\
\text { red }\end{array}$} & $\begin{array}{l}\text { tourniquet right upper } \\
\text { leg } 350 \mathrm{mmHg} 1300-1427\end{array}$ & 84 minutes \\
\hline & & & & & $\begin{array}{l}\text { diathermy plate on left } \\
\text { thigh }\end{array}$ & 110 minutes \\
\hline \multirow[b]{2}{*}{6} & \multirow{2}{*}{$\begin{array}{l}\text { diathermy plate } \\
\text { burn to left thigh }\end{array}$} & \multirow{2}{*}{$\begin{array}{l}\text { open } \\
\text { reduction } \\
\text { internal } \\
\text { fixation left } \\
\text { trimalleolar } \\
\text { fracture }\end{array}$} & \multirow{2}{*}{$\begin{array}{l}41 \text {-year-old } \\
\text { female with nil } \\
\text { comorbidities }\end{array}$} & \multirow{2}{*}{$\begin{array}{l}\text { chlorhexidine } \\
0.5 \% \text { in alcohol } \\
\text { red }\end{array}$} & $\begin{array}{l}\text { tourniquet right upper } \\
\text { leg } 350 \mathrm{mmHg} 1300-1427\end{array}$ & 130 minutes \\
\hline & & & & & $\begin{array}{l}\text { diathermy plate on } \\
\text { left thigh reported as } \\
\text { tourniquet injury }\end{array}$ & 20 minutes \\
\hline 7 & $\begin{array}{l}\text { posterior thigh } \\
\text { burns }\end{array}$ & $\begin{array}{l}\text { Caesarean } \\
\text { section }\end{array}$ & $\begin{array}{l}\text { 40-year-old } \\
\text { female with nil } \\
\text { comorbidities, } \\
\text { healthy baby PEP }\end{array}$ & $\begin{array}{l}\text { aqueous } \\
\text { betadine }\end{array}$ & $\begin{array}{l}\text { diathermy plate left } \\
\text { thigh } \\
\text { Suspected bed as } \\
\text { occlusion due to burns } \\
\text { on back of thighs }\end{array}$ & 94 minutes \\
\hline
\end{tabular}

The only likely source of burn in this instance may have been the end of the light cord which can become hot during use. Therefore, it is not an antiseptic burn; however, it has been included in this brief due to the nature of the injury and its relation to current Work Unit Guidelines (WUGs) in place. Finally, an injury was caused by a diathermy plate rather than an antiseptic. However, it has been included in this brief due to the nature of the injury and its relation to current WUGs in place.

\section{Discussion}

Antiseptic burns are considered a rare adverse intra-operative event. In this quality improvement review, the development of these burns is likely due to several factors. A suspected commonality is that patients may have been resting for prolonged periods of time on moistened surfaces or moistened tourniquets. In regards to risk factors highlighted previously:

- concentration of the antiseptic aqueous betadine and chlorhexidine in alcohol were used 
- absorption into the skin, patient factors allowing permeability or resistance to absorption - one patient had a skin condition which would have increased permeability and susceptibility to antiseptic burn

- exposure time - excluding the diathermy plate burn and suspected light cord burn, the mean time of antiseptic contact was 86 minutes

- occlusion - i.e. theatre table, tourniquets increased absorption of antiseptics

- humidity and moisture - it can only be assumed that there was increased humidity as the surfaces in contact with skin had no moisture vapour transfer capabilities. In particular, the tourniquets may have retained moisture after contact with the antiseptics. It was also assumed that staff members may have applied excessive amounts of antiseptic which saturated drapes and sheets, therefore increasing the risk of injury. The linear lesions in Figure 1 are consistent with 'wet' bedsheets.

\section{Lessons learnt:}

\section{Recommendations and changes to practice}

A cluster of incidents occurred prompting immediate action by nursing leaders. At the time of the original review, February 2016, there had been one further suspected antiseptic burn which occurred during changeover of new surgical (Registrar) teams at our hospital. On prompt review of the patient's clinical notes, it was determined that the theatre protocol, such as changing wet sheets and applying protection under tourniquet, was not followed.
At the time of the cluster of suspected intra-operative chemical burns, immediate action involved:

- review of Australian College of Perioperative Nurses (ACORN)

Standard 5 with nurse unit managers (NUM) and theatre staff

- review of WUGs in conjunction with literature review

- reiteration by the Nurse Educator of WUGs for review within theatre and among theatre staff.

Planning for the future (Accountable staff: NUM and Nurse Educators of theatre)

- The review highlights the importance of pre-operative and post-operative skin assessment.

- There is a need for ongoing education to support staff in theatre, including new graduates or new employees.

- Further actions taken following review and discussion:

- changes to theatre orientation checklist, to ensure saturated drapes and tourniquets are changed prior to the procedure

- e-learning about pressure injury presentation including skin assessment for prevention of antiseptic preparations pooling against patient skin

- changes to education package: 'Nurse education - theatre orientation' now includes tourniquet management in relation to antiseptics and pooling of antiseptics

- the 'Survival guide' (a two-page sheet for casual or agency staff) now includes management of antiseptic preparations

- re-assessment of practices regarding post-operative sponges or showers. There has been a perceived trend in allowing patients to choose whether to have a post-operative sponge or shower. Despite patient-centred care being a priority, this review highlighted a need to educate patients about the purpose of post-operative washing (sponge or shower), thus allowing the patient to make an informed decision about this practice. Our maternity unit and orthopaedics unit were the focus of this education due to the patients identified in the review.

Planning for the future (Accountable staff: Wound Management Service)

- Review patients referred for suspected antiseptic burns.

- Provide support (patient review and implementation of treatment plans) to theatre, recovery or day procedure staff in relation to patients with altered skin integrity who may be at risk of further intraoperative injury.

- Educational sessions about skin assessment and wound management held by the Would Management Service and disseminated to nursing, allied health and medical staff.

\section{Dissemination of results to a wider} nursing and theatre staff community

- In-service for theatres were completed (Nurse Educator will provide further ongoing sessions locally).

- Presentations were prepared for Nursing Grand Rounds and Multidisciplinary Grand Rounds locally.

- Presentations to theatre and surgical staff within the Australian and international community.

- Publication to share lessons learnt, with the wider operating theatre team community. Ethics approved HREC/16/QPCH/52. 


\section{Conclusion}

This was the quality improvement activity which was developed from a cluster of suspected intra-operative antiseptic burns. Risk factors for developing these types of burns are already identified in the literature. There has only been one incident identified over the last year since the review, which highlighted to us as nursing leaders that our work and education must be ongoing and filter through to the medical and surgical specialties. Locally, it was identified that ongoing education and support programs are required to assist in educating the changing workforce, thus keeping staff up to date with best practice, local policy and procedure and to keep our patients safe and free from harm.

\section{References}

1. Sivanthasan N, Ramamurthy N, Pabla R. Chemical burns associated with chlorhexidine-alcohol solution: An avoidable complication. J Burn Care Res 2010;31(5):833.

2. Queensland Health. Guideline for surgical skin disinfection, Version 2 [Internet]. Brisbane: Queensland Health; 2012 [cited 2015 Dec 20]

3. Leaper D, Ousey K. Evidence update on prevention of surgical site infection. Curr Opin Infect Dis 2015;28(2):158-163.

4. Paranagua T, Bezerra A, Silva A, Filho $F$. Prevalence of no harm incidents and adverse events in a surgical clinic. Acta Paul Enferm 2013;26(3):256-262.

5. Wall J, Divito S, Talbot S. Chlorhexidine gluconate-impregnated central line dressings and necrosis in complicated skin disorder patients. J Crit Care 2014;29:1130. e1-1130.e4.
6. Warner P, Coffee T, Yowler C. Outpatient burn management. Surg Clin North Am 2014;94(4): 879-892.

7. Sanders T, Hawken S. Chlorhexidine burns after shoulder arthroscopy. Am J Orthop 2012; 41(4):172-174.

8. Queensland Health. Work Unit Guideline: Skin preparation in the operating suite 201304.03/MN/Proc-Att1 Version 0.3. Brisbane; Queensland Health: 2015.

9. Sävervall C, Lærke S, Thomsen S. Dermatological diseases associated with pregnancy: Pemphigoid gestationis, polymorphic eruption of pregnancy, intrahepatic cholestasis of pregnancy, and atopic eruption of pregnancy. Dermatol Res Pract 2015:1-7. 